\title{
Editorial, July 2009: Darwinian Thinking
}

As most philosophers are pre-disposed to favour intellectual freedom, J.S. Mill's defence of free intellectual enquiry and discussion in On Liberty is normally accepted without demur. While there may be no general objection to that, in one respect what he argues deserves slightly more examination than it customarily receives.

The respect in question is the underlying assumption, that if competing views are allowed to fight it out without interference, the truer ones will eventually come through. This is, in a sense, a Darwinian stance, appropriate enough for the time (1859 being the date of publication for both Mill and Darwin): the fittest opinions will most likely survive.

By definition, they will, if by 'fittest' one means those with the best survival capacity in the particular ideological environment. But they may not at the best or the truest in any other sense, and that is where Mill's Darwinism may fall apart.

As is well known in 2009 there are doubtless more thinkers thinking and writing than there have ever been. But in a serious sense is there greater effective diversity of opinion, or on philosophical matters more truth, than say in classical Athens or in fifteenth century Florence or in the Europe of Descartes, Hobbes, Leibniz and Locke?

What too bland a Millianism fails to take into account is the effect of fashion, the ecology of the intellectual environment, so to speak, which exists in philosophy as much as in any other area of life. We may think that there are a hundred flowers blooming in philosophy in academia, but it may not look like that to our successors, looking back on us in years to come.

It is, of course, true that philosophical theories regarded as totally dead thirty years ago are now ruling the roost in the most prestigious circles (and, conversely, there is very little now of some of the more popular approaches from the 1950s). But we may delude ourselves if we think this has more to do with the rationality of a Millian intellectual slug-fest than with a change of Darwinian ecology of thought. What has actually made Meinongianism respectable now, when it wasn't in the 1950 s, to say nothing of the plurality of worlds, possible 


\section{Editorial}

and impossible? This thought is not an argument against freedom of discussion as much as a question as to whether we are as intellectually free as, reading Mill, we might like to think we are; rather than we thinkers being free, certain lines of thought - and their proponents may have their times, as fashions and interests change. 